\title{
Application of some insensitive probiotic lactic acid bacteria and ginger as functional dairy products
}

\author{
Allam MG ${ }^{1 *}$, Gomaa MAE, Ayad EHE and Darwish SM²
}

Department of Food Science, Faculty of Agriculture, Saba Basha, Alexandria University, Saba Basha, Alexandria 21527, Egypt

Allam MG, Gomaa MAE, Ayad EHE, Darwish SM 2018 - Application of some insensitive probiotic lactic acid bacteria and ginger as functional dairy products. Microbial Biosystems 3(1), $60-73$

\begin{abstract}
The use of dairy-based functional foods has increased markedly over the last few years. Ginger is believed to exert a wide range of therapeutic properties. This study aimed to evaluate probiotic properties of twenty Lactic acid bacteria to apply in functional fermented milk fortified with fresh ginger juice to increase the therapeutic and nutritional effects of the product. Ginger juice was prepared from ginger rhizomes through sorting, washing, peeling, crushing and crude juice extraction. It was assayed for antibacterial activity by minimal inhibitory concentration against antibiotic resistant pathogenic bacteria (E. coli BA 12296, Bacillus subtilis DB100, Klebsiella pneumoniaa ATCC12296, Salmonella senftenberg ATCC 8400, Staphylococcus aureus NCTC 10788, Staphylococcus epidermidis ATCC 35984). Total phenol, total flavonoids and antioxidant activity were determined, ginger juice showed an antibacterial activity and antioxidant activity. Twelve strains out of twenty were resistant to bile salts concentrations $(0.2,0.3$ and $0.4 \mathrm{w} / \mathrm{v})$, to acid conditions $(\mathrm{pH} 2.0,3.0$ and 4.0) and were able to grow in the presence of 0.2 and $0.4 \mathrm{w} / \mathrm{v}$ of phenol. Seven strains (Lactobacillus delbrueckii subsp. delbrueckii KT615, Lb. brevis KP653, Lb. delbrueckii subsp. lactis KP645, Lb. plantarum KP623, Lb. paracasei subsp. tolerans WT631, Enterococcus faecalis BM711, Enterococcus faecium BT734) had the ability to adhere to rabbit intestinal epithelial cells in-vitro, and were resistant to ginger juice. Ginger juice concentration showed indirect relationship with the milk coagulation time and direct with syneresis of fermented milk. It was showed that used $2 \%$ of ginger juice concentrations was the best results on fermented milk products.
\end{abstract}

Key words - Fresh ginger juice, antioxidant, fermented milk, probiotic, syneresis, yogurt.

\section{Introduction}

Functional foods are recognized as having physiological benefits as well those of basic nutrition which called nutraceuticals (Bigliardi and Galati 2013). Nutraceuticals are a natural product sold in dosage form (capsules, tablets, powders, etc). Functional dairy products are the healthy food products especially probiotics products which were defined as products have a live microorganism that when treated in suitable amounts give a health benefit to the host (FAO/WHO 2002). In recent years, different studies support the importance of probiotics as 
apart of healthy diet for humans and animals and as a way to provide a natural, safe and effective barrier against microbial infections (Markowiak, and Śliżewska, 2017; Kerry et al. 2018; Vijayaram and Kannan 2018). Lactic acid bacteria (LAB) are non-pathogenic bacteria that belong to the major group of probiotic natural microbiota in the gastrointestinal tract (GIT) and preserve an efficient balance between useful and harmful bacteria.

Recent studies have shown the role of lactic acid bacteria as a probiotic and its functional and health properties. Ayyash et al. (2018) showed in-vitro the health-promoting effects (anticancer activity, $\alpha$-amylase and $\alpha$-glucosidase inhibitions, ACE-inhibition, antioxidant and proteolytic activity) of camel milk fermented with three probiotic strains of Lactobacillus spp. were isolated from camel milk. Also, the effects of probiotic LAB supplementation on inflammation and oxidative stress was studied in many studies due to the probiotic role in immune system modulation and the anti-inflammatory response (Plaza-Díaz et al. 2017; Badehnoosh et al. 2018). In another study of nine probiotic LAB strains were isolated from different sources and identified have high antagonistic activity. There is one isolate Lactococcus lactic subsp. lactis BO37 has manifested the highest cholesterol removal ability in vitro (Shehata et al. 2016).

Ginger rhizome has been used as a medicinal herb due to its high content of antioxidants and anti-inflammatory properties. In the last decades, ginger has been used in the medicinal application against pathogenic microorganisms. It was reported that ginger has antipyretic, analgesic and anti-cancer properties (Du et al. 2018; Mathew 2018). In addition, the rhizome of ginger has many nutrients as fats, carbohydrates, protein, fiber and water. It contains volatile component which confers the unique flavor of the spice. It has been mentioned that: "Round amongst them (the righteous in paradise) is passed vessels of silver and goblets made of glass a cup, the admixture of which is ginger" (The Holy Quran 76:15-17). Ginger is a common spice which contains bioactive constituents such as zingerone, shogaols, paradol and gingerols. It has been extensively studied for its pharmacological and biological activities (Foster 2011; Singh et al. 2018). Due to the low toxicity of ginger, its contents of bioactive components and its broad spectrum of biological and pharmacological applications, has been increasingly used (Aly et al. 2013).

Antioxidants were defined as "substance that in small quantities are able to prevent or greatly retard the oxidation of easily oxidizable nutrients such as fats" (Skibsted 2010). It can prevent oxidative damage to food during processing, storage and preparation of meals. Antioxidants may accordingly help the development of more healthy food with low levels of lipid and protein oxidation products. Also, antioxidants have more compounds able to scavenge free radicals such as peroxide, hydroperoxide or lipid peroxyl and thus inhibit the oxidative mechanisms that lead to degenerative diseases (Valko et al. 2006; Al-Rimawi et al. 2017). Ginger has antioxidant activity by the antioxidant components analyzed such as polyphenols, vitamin $\mathrm{C}$, flavonoids and tannins they have displayed strong antioxidant activity in- vitro (Atashak 2014).

Ginger also showed antimicrobial activity against pathogenic bacteria like some Salmonella strains, Staphylococcus aureus, Yersinia enterocolitica, Escherichia coli and Listria monocytogenes, Saccharomyces cerevisia and filamentous fungi e,g. Aspergillus (Aruna et al. 2014; El-Khalek et al. 2016). Therefore, many studies have been carried by several investigators suggested ginger as a preservitaive and medicatication supplement against microbial spoilage of food and for topical antifungal or antibacterial treatment (Policegoudra et al. 2007; Hasan et al. 2012).

Due to shortage of research concerning probiotic fermented dairy products fortified with fresh ginger juice due to its antibacterial properties, this work aimed to: 1 - use the ginger juice in dairy products to enhance their functional and nutritional properties, 2- selection of insensitive 
probiotic LAB as a supplement, 3- study the sensory evaluation and properties of the product, and 4 - produce innovate new fermented dairy products.

\section{Materials and Methods}

\section{Lactic acid bacteria strains}

Twenty strains of LAB (Table 1) have antimicrobial activity against culture of enteropathogenic E. coli obtained from the culture collection of NIZO (Food Research, Ede, The Netherlands) were kindly supplied by culture collection of Faculty of Agriculture Saba Basha, Alexandria University (FABA).

Table 1 Lactic acid bacteria strains

\begin{tabular}{lll}
\hline No & strains code & \\
\hline 1 & KT642 & Lactobacillus fermentum Beijerinck \\
2 & KP623 & Lactobacillus plantarum (Orla-Jensen) Bergey \& al \\
3 & KP642 & Lactobacillus casei (Orla-Jensen Hansen \& Lessel \\
4 & KP645 & Lactobacillus delbrueckii subsp. lactis (Leichmann) Beijerinck \\
5 & KP653 & Lactobacillus brevis (Orla-Jensen) Bergey \& al \\
6 & KP654 & Lactobacillus debrueckii subsp. lactis (Leichmann) Beijerinck \\
7 & KT724 & Enterococcus faecium (Orla-Jensen) Schleifer \& Kilpper-Bälz \\
8 & KT615 & Lactobacillus delbrueckii subsp. delbrueckii (Leichmann) Beijerinck \\
9 & EP6494 & Leuconostoc oenos Garvie \\
10 & GP614 & Enterococcus durans (Sherman and Wing) Collins et al. \\
11 & GP615 & Enterococcus faecalis (Andrewes \& Horder, 1906) Schleifer \& Kilpper-Bälz \\
12 & WT631 & Lactobacillus paracasei subsp. tolerans Collins \& al. \\
13 & BM711 & Enterococcus faecalis (Andrewes \& Horder, 1906) Schleifer \& Kilpper-Bälz \\
14 & BP631 & Lactobacillus casei (Orla-Jensen) Hansen \& Lessel \\
15 & BP633 & Enterococcus seriolicida Collins et al. \\
16 & BP639 & Lactobacillus paracasei subsp. Paracasei Collins \& al. \\
17 & BT611 & Enterococcus durans \\
18 & BT615 & Enterococcus faecalis (Andrewes \& Horder, 1906) Schleifer \& Kilpper-Bälz \\
19 & BT6110 & Enterococcus faecalis (Andrewes \& Horder, 1906) Schleifer \& Kilpper-Bälz \\
20 & BT734 & Enterococcus faecium (Orla-Jensen, 1919) Schleifer \& Kilpper-Bälz \\
\hline
\end{tabular}

\section{Food borne pathogenic bacteria strains}

Six pathogenic bacterial strains namely: E. coli BA 12296, Bacillus subtilis DB100, Klebsiella pneumoniaa ATCC12296, Salmonella senftenberg ATCC 8400, Staphylococcus aureus NCTC 10788, Staphylococcus epidermidis ATCC 35984 were kindly provided by Scientific Research and Technological Applications (SRTA-City), Genetic Engineering and Biotechnology Research Institute (GEBRI), Borg Al-Arab in Alexandria, Egypt. Strains were grown in nutrient broth medium (Lab M, UKSA) at $37^{\circ} \mathrm{C}$ for $24 \mathrm{~h}$.

\section{Assessment of potential probiotic LAB}

Acid resistance and bile salt tolerance were assayed using the method of Charteris et al., (1998) and Zinedine and Faid (2007) with some modification. The strains were incubated at $37^{\circ} \mathrm{C} / 6 \mathrm{~h}$, then optical density was measured at $650 \mathrm{~nm}\left(\mathrm{O} . \mathrm{D}_{650}\right)$ using a Spectrophotometer (Apel-pD-303UV Spectrophotometer, Japan). Strains were inoculated $(10 \% \mathrm{v} / \mathrm{v})$ into MRS 
broth previously adjusted to $\mathrm{pH}(2.0,3.0$ and $4.0 \pm 0.1)$ with $\mathrm{HCl}$. MRS broth containing bile salts was prepared by the addition of $0.2,0.3$ and $0.4 \%(\mathrm{w} / \mathrm{v})$ bile salts (Biolife, Milano, Italy). Overnight cultures were inoculated $10 \%(\mathrm{v} / \mathrm{v})$ into MRS broth and incubated at $37^{\circ} \mathrm{C}$. Bacterial growth was followed for $6 \mathrm{~h}$ by measuring the optical density at $650 \mathrm{~nm}$.

MRS broth and M17 were modified with 0.2 to $0.4 \%$ phenol to determine the phenol tolerance of the isolates according to the method described by Aswathy et al. (2008). Inoculated cultures were incubated at $37^{\circ} \mathrm{C}$ for $24 \mathrm{~h}$. Absorbance (as a function of growth) was measured at $600 \mathrm{~nm}$ after $24 \mathrm{~h}$. This experiment was performed in triplicates.

\section{Adhesion to rabbit intestinal epithelial cells Adherence assay}

Epithelial cells were obtained from the small intestines of rabbits $(2.5 \pm 0.25 \mathrm{Kg})$ as previously described by Alnaqdy et al. (2005). The small intestine of fresh slaughtered healthy rabbits was removed and chilled in cold physiological saline solution and brought to the laboratory within $30 \mathrm{~min}$. Seven $\mathrm{cm}$ sections of freshly collected duodenum from rabbit was slit open, washed with cold PBS pH $7.2\left(4^{\circ} \mathrm{C}\right)$ and incubated in a buffer containing $10 \mathrm{mM}$ EDTA $\mathrm{pH} 6.8$ for $20 \mathrm{~min}$. The section was then rinsed twice with phosphate buffer saline (PBS) to remove the EDTA then placed in $5 \mathrm{ml}$ of cold PBS. Epithelial cells were dislodged by rubbing the intestine with a sterile syringe plunger and the epithelial-rich supernatant (which was identified from other cell fractions, such as leukocytes, on the basis of cell size and morphology) was removed with a sterile Pasteur pipette, pelleted by centrifugation at $100 \mathrm{xg}$ for $10 \mathrm{~min}$, washed twice with PBS (100 xg for $5 \mathrm{~min}$ ) and then resuspended in $2 \mathrm{ml}$ PBS. The number of epithelial cells was adjusted to $10^{6}$ cell $/ \mathrm{ml}$ using a haemocytometer.

One $\mathrm{ml}$ containing $1 \times 10^{8}$ cells of LAB strains were mixed with equal volume of epithelial cells at $10^{6}$ cells $/ \mathrm{ml}$ and incubated for $1 \mathrm{~h}$ at $37^{\circ} \mathrm{C}$ in a shaker water bath (Kottermann, D.3162 Germany). Epithelial cells were then pelleted by centrifugation at $100 \mathrm{x} \mathrm{g}$ for $10 \mathrm{~min}$, washed with PBS to remove any unattached bacteria and resuspended in $2 \mathrm{ml}$ PBS. Microscopic slides were prepared and stained with crystal violet. The numbers of Lactobacillus cells attached to single epithelial cells were counted under the oil immersion using a light microscopy (Optika microscopes, Italy). E. coli was processed in the same manner as a control. This experiment was performed once counting the adhered bacteria to 50 epithelial cells.

\section{Ginger juice extract}

Ginger juice was prepared according to the method of Akhani et al. (2004) in which fresh rhizomes of ginger $(2 \mathrm{Kg})$ obtained from local markets in Alexandria, Egypt were crushed and squeezed in muslin / cotton cloth to obtain the juice, which was stored in the refrigerator at $2-7^{\circ}$ $\mathrm{C}$ in a well-closed dark glass container.

\section{Chemical analysis of ginger juice}

Total soluble solids, ash content and $\mathrm{pH}$ were determined as described by Official Methods of Analysis of AOAC International (2016).

\section{Total phenol contents}

Total phenolic contents of ginger juice $(\mathrm{ml})$ were determined using Folin-Ciocalteu reagent according to the method described by Stoilova et al. (2007). 


\section{Total flavonoids determination}

The aluminum chloride colorimetric assay method was used to determine total flavonoid content of ginger juice $(\mathrm{ml})$ and use catechol as an equivalent according to the method described by Sakanaka et al. (2005).

\section{Free radical scavenging determination using DPPH method}

Antioxidant activities of ginger juice was evaluated through free radical scavenging effect using 1,1-diphenyl-2-picrylhydrazyl (DPPH) radical according to the method proposed by Akowuah et al. (2005).

\section{Antimicrobial activity of ginger against the pathogenic bacteria}

The minimal inhibition concentration (MIC) values of the ginger juice against pathogenic bacteria was determined after $48 \mathrm{~h}$ of incubation at $37^{\circ} \mathrm{C}$ using microdilution method (Wang et al. 2010). For the determination of minimal growth concentration (MGC), a portion of liquid (5 $\mu \mathrm{l})$ from each plate well that exhibited no growth were taken and then incubated at $37^{\circ} \mathrm{C}$ for $24 \mathrm{~h}$ (Kang et al. 2011).

\section{Antagonistic effect of ginger juice on selected probiotic strains}

The disc diffusion assay (Pessoa et al. 2017) was used for detection of antagonistic effect of filtered ginger juice against 12 selected probiotic LAB strains. Loop full growths from probiotic bacterial strains were inoculated into MRS broth, incubated at $37{ }^{\circ} \mathrm{C}$ for $18 \mathrm{~h}$ containing $10^{8} \mathrm{CFU} / \mathrm{ml}$. Cotton swab was dipped into adjustment suspension and streak the entire MRS Agar media surface of plates and the plates were left for $15 \mathrm{~min}$ at room temperature to dry. A half $\mathrm{cm}$ wide filter paper discs were sterilized and $10 \mu \mathrm{l}$ of the ginger juice was placed on the disc. All of plate tested was incubated at $37^{\circ} \mathrm{C}$ for overnight. After $24 \mathrm{~h}$ of incubation, ginger juice was noted for zone of inhibition for all probiotic strains. The diameters of the zone of inhibitions were measured by measuring scale in millimeter $(\mathrm{mm})$.

\section{Preparation of ginger yoghurt}

Pasteurized skim milk (12\% SNF) was warmed to $42^{\circ} \mathrm{C}$ and cultured with $1-2 \%$ of the common yoghurt cultures Yo-Mix \& 200 DCU (Danisco, USA) with different concentration of ginger juice $(0,1,2,5,10$ and $15 \%)$. The mix was distributed in cups and incubated at $42^{\circ} \mathrm{C}$ for 3 $\mathrm{h}$, then cooled and stored at $4^{\circ} \mathrm{C}$ (Tamime and Robinson 1985).

\section{Syneresis}

One hundred grams of ginger yoghurt samples with different concentration of ginger juice $(0,1,2,5,10$ and $15 \%)$ were placed on a filter paper resting on a top of a funnel. After $2 \mathrm{~h}$ of drainage at $7^{\circ} \mathrm{C}$, the quantity of whey out of the total weight $(100 \mathrm{~g})$ of the yoghurt collected in $50 \mathrm{~mL}$ graduated cylinder was used as an index of syneresis (Srisuvor et al. 2013).

\section{Preparation of ginger probiotic fermented milk}

Pasteurized skimmed milk (12\% SNF) containing $2 \%$ ginger juice was warmed to $42^{\circ} \mathrm{C}$, and cultured with $1-2 \%$ of selected individual probiotic LAB starter strains, Lb. delbrueckii subsp. delbrueckii KT615, Lb. brevis KP653, Lb. delbrueckii subsp. lactis KP645, Lb. plantarum KP623, Lb. paracasei subsp. tolerans WT631, Enterococcus faecalis BM711 and Enterococcus faecium BT734. All strains were subcultured $(1 \%, \mathrm{v} / \mathrm{v})$ twice at $37^{\mathrm{O}} \mathrm{C}$ overnight in $12 \%(\mathrm{w} / \mathrm{v})$ sterile RSM (Reconstituted skim milk) prior to use as a bulk culture (2\%, v/v) (Ong et al. 2006). The mix was distributed in cups, incubated at $42^{\circ} \mathrm{C}$ for $3 \mathrm{~h}$, then cooled and stored at $4{ }^{\circ} \mathrm{C}$. 


\section{Sensory evaluation of ginger probiotic fermented milk}

Sensory evaluation was performed by overall quality score of the conventional fermented milk according to Majchrzak et al. (2010) and Allam et al. (2017). It was conducted by a trained panel of 10 assessors ( 8 men and 2 women, aged from 27 to 58 years) at Faculty of Agriculture, Saba Basha Alexandria University. The method describes all sensation perceived when evaluating a sample by different categories as appearance, aroma, flavor/taste, texture and after taste. Every category is described by certain descriptors, which are discussed and agreed upon the definitions by the panelists during evaluation. The averages of sensory evaluation data with standard deviations were determined.

\section{Statistical analysis}

Statistical analysis was performed using Analytical Software SPSS ${ }^{\circledR}$ 13.0 (Statistical Package for the Social Sciences) (2005). Values are mean of \pm SD (standard deviation) of three replicates. Differences were considered significant at $\mathrm{P}<0.05$.

\section{Results and Discussion \\ Assessment of probiotic criteria of LAB strains}

The characteristics of probiotic including the demonstration of bile tolerance in the small intestine, acid resistance and adherence to host epithelial tissue are the most important representative selection criteria of probiotics (Olejnik et al. 2005; Bubnov et al. 2018). Table (2) illustrates the probiotic criteria of the 20 selected LAB strains. The results indicated that out of the twenty strains, twelve strains ( $L b$. fermentum KT642 Lb. plantarum KP623, Lb. del. subsp. lactis KP645, Lb. brevis KP653, Enterococcus faecium KT724, Leuconostoc oenos EP6494, Lb. paracasei subsp. tolerans WT631, Enterococcus faecalis BM711, Lb. casei BP631, Enterococcus durans BT611, Enterococcus faecium BT734 and Lb. del. subsp. delbrueckii KT615) have the ability to grow in bile salt condition and other eight strains have medium ability to grow in the same condition. The same twelve strains grow well and resist acid condition, five strains ( $L b$. del. subsp. lactis KP654, Enterococcus durans GP614, Lb. paracasei subsp. paracasei BP639, Enterococcus faecalis BT615 and Enterococcus faecalis BT6110) showed medium growth while three strains ( $\mathrm{Lb}$. casei KP642, Enterococcus faecalis GP615 and Enterococcus seriolicida BP633) were sensitive to acid. Eleven strains were able to grow in phenol (0.2, and $0.4 \%$ ), five strains ( $\mathrm{Lb}$. casei, KP642, Lb. del. subsp. lactis KP654, Enterococcus durans GP614, Enterococcus durans BT611 and Enterococcus faecalis BT615) grow only in media containing $0.2 \%$ phenol, and the rest strains were sensitive to phenol condition (Enterococcus faecalis GP615, Enterococcus seriolicida BP633, Lb. paracasei subsp. paracasei BP639 and Enterococcus faecalis BT6110).

The data also indicated that seven strains have the ability to adhere to rabbit intestinal epithelial cells ( $L b$. del. subsp. delbrueckiil KT615, Lb. brevis KP653, Lb. del. subsp. lactis KP645, Lb. plantarum KP623, Lb. paracasei subsp. tolerans WT631, Enterococcus faecalis BM711 and Enterococcus faecium BT734), whereas three strains ( $L b$. fermentum KT642, Enterococcus faecium KT724 and Lb. casei BP631) have weak ability of adherence and the other five strains ( $\mathrm{Lb}$. del. subsp. lactis KP654, Enterococcus durans GP614, Lb. paracasei subsp. paracasei BP639, Enterococcus faecalis BT615 and Enterococcus faecalis BT6110) couldn't attach to rabbit intestinal epithelial cells. 
Table 2 Assessment of probiotic criteria of LAB strains

\begin{tabular}{|c|c|c|c|c|c|c|c|c|c|}
\hline \multirow[t]{2}{*}{ LAB strains } & \multicolumn{3}{|c|}{$\begin{array}{c}\text { Acid } \\
\text { tolerance } \\
(\mathrm{pH})\end{array}$} & \multicolumn{3}{|c|}{ bile tolerance $\%$} & \multicolumn{2}{|c|}{$\begin{array}{c}\text { Phenol } \\
\text { tolerance\% }\end{array}$} & \multirow{2}{*}{$\begin{array}{l}\text { Number of LAB } \\
\text { strains adhered to } \\
\text { epithelial cell * }\end{array}$} \\
\hline & 2 & 3 & 4 & 0.20 & 0.30 & 0.40 & 0.20 & 0.40 & \\
\hline Lb. fermentum KT642 & + & + & + & + & + & + & + & + & $23.4 \pm 4.3$ \\
\hline Lb. plantarum KP623 & + & + & + & + & + & + & + & + & $45.4 \pm 6.7$ \\
\hline Lb. casei KР642 & - & - & - & + & - & - & + & - & ND \\
\hline Lb. del. subsp. lactis KP645 & + & + & + & + & + & + & + & + & $46.3 \pm 3.6$ \\
\hline Lb. brevis KP653 & + & + & + & + & + & + & + & + & $46.8 \pm 7.2$ \\
\hline Lb. del. subsp. lactis KP654 & - & + & + & + & + & - & + & - & $12.6 \pm 5.8$ \\
\hline Enterococcus faecium KT724 & + & + & + & + & + & + & + & + & $32.9 \pm 4.2$ \\
\hline Leuconostoc oenos EP6494 & + & + & + & + & + & + & + & + & $40.7 \pm 4.4$ \\
\hline Enterococcus durans GP614 & - & + & + & - & + & - & + & - & $15.8 \pm 3.7$ \\
\hline Enterococcus faecalis GP615 & - & - & - & - & - & + & - & - & ND \\
\hline Lb. paracasei subsp. tolerans WT631 & + & + & + & + & + & + & + & + & $46.1 \pm 6.3$ \\
\hline Enterococcus faecalis BM711 & + & + & + & + & + & + & + & + & $45.4 \pm 6.2$ \\
\hline Lb. casei BP631 & + & + & + & + & + & + & + & + & $36.9 \pm 6.4$ \\
\hline Enterococcus seriolicida BP633 & - & - & + & - & + & - & - & - & ND \\
\hline Lb. paracasei subsp. paracasei BP639 & - & - & + & + & + & - & - & - & $13.1 \pm 5.4$ \\
\hline Enterococcus durans BT611 & - & + & - & + & + & + & + & - & $32.5 \pm 4.1$ \\
\hline Enterococcus faecalis BT615 & - & + & + & + & + & - & + & - & $12.4 \pm 6.9$ \\
\hline Enterococcus faecalis BT6110 & - & - & + & - & + & + & - & - & $5.4 \pm 4.9$ \\
\hline Enterococcus faecium BT734 & + & + & + & + & + & + & + & + & $41.2 \pm 2.4$ \\
\hline Lb. del. subsp. delbrueckii KT615 & + & + & + & + & + & + & + & + & $42.6 \pm 2.6$ \\
\hline
\end{tabular}

* Number of LAB strains adhered to epithelial cell (total of 50 epithelial cell were studied)

*: Data are represented in means of $(3 n) \pm S D$; ND, not determined

\section{Chemical analysis of ginger juice}

Chemical composition of ginger juice is exhibited in Table (3). Results showed that ginger juice contains 79.8\% moisture, $20.5 \%$ TSS and 1.17\% Ash. These results almost agreed with Zadeh et al. (2014).

\section{Total phenolic and flavonoids content}

Antioxidants contents, phenolic and flavonoids, of ginger juice are presented in Table (3). Results clearly indicated that ginger juice has high content of total phenols with mean a value of $161.074 \mathrm{mg} \mathrm{GAE} / 100 \mathrm{~g}$ juice which higher than that of results obtained by Maizura et al. (2011) (101.56 mg GAE/100g ginger extract). Flavonoid content of ginger juice was $27.317 \mathrm{mg}$ catechol /g. Pawar et al. (2011) found that flavonoid content in ginger extracts ranged from 1.3 to $3.8 \mathrm{mg}$ quercetin $/ \mathrm{g}$. 


\section{Antioxidant capacity}

Accordingly, antioxidant potentials of ginger juice to scavenge DPPH is presented in Table (3), This result in agreement with Mošovská et al. (2015), who mentioned that ginger extract is a good source of polyphenolic compounds including gingerols, shogaols, paradols and gingerdions. Our results suggested that demonstrating of that ginger juice can be performed as a natural antioxidant in the functional food and pharmaceutical industries. This may be refered to the phenolic compounds of ginger juice which of considerable interest and are increasingly becoming a subject of intensive research due to their bioactive properties (Ignat and Popa 2011; Tohma et al. 2017). So, the support of fermented milk products with ginger can increase the functional properties of the product.

Table 3 Chemical composition, antioxidants contents and potentials of ginger juice

\begin{tabular}{ll}
\hline Parameters & Ginger juice $100 \mathrm{ml}$ \\
\hline Moisture\% & $79.8 \pm 2.5$ \\
TSS\% & $20.5 \pm 1.4$ \\
$\mathrm{pH}$ & $6.4 \pm 0.2$ \\
Ash\% & $1.17 \pm 0.05$ \\
*Total phenol mg/g & $161.075 \pm 6.2$ \\
$* *$ Total flavonoids $\mathrm{mg} / \mathrm{g}$ & $27.317 \pm 2.4$ \\
$* * *$ DPPH inhibition $(\mathrm{mg} / \mathrm{ml})$ & $80.6 \pm 0.8$ \\
\hline
\end{tabular}

*Total phenolic was expressed as gallic acid equivalents (GAE) mg/g sample.

**Total flavonoids were expressed as $\mathrm{mg}$ catechol/g sample.

***IC50 $(\mathrm{mg} / \mathrm{mL})$ : Inhibitory concentration at which $50 \%$ of DPPH radicals are scavenged.

Twelve selected probiotic LAB strains are exhibited in Table (4). The results showed the antagonistic effect of ginger against five tested probiotics $(\mathrm{Lb}$. fermentum KT642, Enterococcus faecium KT724, Leuconostoc oenos EP6494, Lb. casei BP631, Enterococcus durans BT611), while seven strains were insensitive to ginger juice.

Table 4 The antagonistic effect of ginger juice against selected probiotic strains

\begin{tabular}{lcc}
\hline Strains & Resistance strains & Inhibitions zone (mm) \\
\hline Lb. fermentum KT642 & - & 20 \\
Lb. plantarum KP623 & + & $\mathrm{ND}$ \\
Lb. del. subsp. lactis KP645 & + & $\mathrm{ND}$ \\
Lb. brevis KP653 & + & $\mathrm{ND}$ \\
Enterococcus faecium KT724 & - & 14 \\
Lb. del. subsp. delbrueckii KT615 & + & $\mathrm{ND}$ \\
Leuconostoc oenos EP6494 & - & 24 \\
Lb. paracasei subsp. tolerans WT631 & + & $\mathrm{ND}$ \\
Enterococcus faecalis BM711 & + & $\mathrm{ND}$ \\
Lb. casei BP631 & - & 17 \\
Enterococcus durans BT611 & - & 16 \\
Enterococcus faecium BT734 & + & $\mathrm{ND}$ \\
\hline ND: not detected & &
\end{tabular}




\section{Antimicrobial activity of ginger against the pathogenic bacteria}

The data presented in Table 5 shows that ginger juice exhibited high antibacterial activity against all tested pathogenic bacteria. It was more effective against Staphylococcus aureus NCTC 10788 (MIC $100 \mu \mathrm{l} / \mathrm{ml}$ and MGC $150 \mu \mathrm{l} / \mathrm{ml}$ ), as compared to other strains. Bacillus subtilis DB100 showed less sensitivity to ginger juice (MIC $200 \mu \mathrm{l} / \mathrm{ml}$ and MGC $250 \mu \mathrm{l} / \mathrm{ml}$ ). These results agreed with those of (Panpatil et al. 2013; Islam et al. 2014).

Table 5 Minimal inhibitory concentration of ginger juice $(\mu 1 / \mathrm{ml})$ against the pathogenic bacteria

\begin{tabular}{|c|c|c|c|c|c|c|c|c|c|c|c|}
\hline \multicolumn{2}{|c|}{$\begin{array}{c}\text { Staphylococcus } \\
\text { epidermidis ATCC } \\
35984\end{array}$} & \multicolumn{2}{|c|}{$\begin{array}{c}\text { Staphylococcus } \\
\text { aureus NCTC } \\
10788 \\
\end{array}$} & \multicolumn{2}{|c|}{$\begin{array}{c}\text { Salmonella } \\
\text { senftenebera } \\
\text { ATCC } 8400 \\
\end{array}$} & \multicolumn{2}{|c|}{$\begin{array}{c}\text { Klebsiella } \\
\text { pneumoniaa } \\
\text { ATCC12296 } \\
\end{array}$} & \multicolumn{2}{|c|}{$\begin{array}{c}\text { E. coli BA } \\
12296\end{array}$} & \multicolumn{2}{|c|}{$\begin{array}{l}\text { Bacillus } \\
\text { subtilis } \\
\text { DB100 }\end{array}$} \\
\hline MGC & MIC & $\mathrm{MGC}$ & MIC & MGC & MIC & MGC & MIC & MGC & MIC & MGC & MIC \\
\hline 200 & 150 & 150 & 100 & 200 & 150 & 200 & 150 & 200 & 150 & 250 & 200 \\
\hline
\end{tabular}

*Minimum inhibitory concentration (MIC) and minimum Growth concentration (MGC) values are given as $\mu 1 / \mathrm{ml}$ for ginger juice.

\section{Properties of ginger yoghurt}

The effect of adding different concentration of ginger juice to produce ginger yoghurt and its properties showed in Table 6 . The syneresis increased with high percentage of ginger juice and vice versa coagulation time. Once again the results in agreement with those reported by Su et al. (2009) which showed that ginger with milk clotting activity has been traditionally used in the preparation of ginger milk curd in China. The results also indicated that yoghurt supplemented with $2 \%$ ginger juice produced acceptable ginger yoghurt with excellent flavor. While by increasing ginger juice concentration from 5 to $15 \%$ resulted in an unacceptable flavor due to an oily substance called gingerol (Ajav and Ogunlade 2014).

Table 6 Properties of ginger yoghurt with different concentration

\begin{tabular}{lllllll}
\hline \multirow{2}{*}{ Parameters } & \multirow{2}{*}{ control } & \multicolumn{3}{l}{ concentration of ginger juice } & & \\
\cline { 3 - 6 } & & $1 \%$ & $2 \%$ & $5 \%$ & $10 \%$ & $15 \%$ \\
\hline Syneresis (\%) & 24.15 & 24.49 & 26.06 & 28.43 & 30.01 & 36.64 \\
Time of coagulation (min) & 240 & 220 & 145 & 36 & 10 & 0 \\
pH of culture milk & 4.53 & 4.72 & 4.95 & 5.02 & 5.16 & 6.13 \\
$\begin{array}{l}\text { Flavor (out of 5) } \\
\text { The organoleptic performances } \\
\text { of ginger yoghurt }\end{array}$ & $4.92 \pm 0.2$ & $4.93 \pm 0.1$ & $4.95 \pm 0.2$ & $3.25 \pm 0.4$ & $2.03 \pm 0.3$ & $1.45 \pm 0.5$ \\
\hline
\end{tabular}

The results are mean of 5 samples with standard deviation

$>$ acceptable $(>3.65)$; acceptable $(\geq 3.50)$; unacceptable $(<2.00)$

\section{Sensory evaluation of probiotic fermented milk containing $\mathbf{2 \%}$ ginger juice}

Table (7) illustrated seven probiotics strains, Lb. del. subsp. delbrueckii KT615, Lb. brevis KP653, Lb. del. subsp. lactis KP645, Lb plantarum KP623, Lb. paracasei subsp. tolerans WT631, Enterococcus faecalis BM711 and Enterococcus faecium BT734, were used in making probiotic fermented milk containing $2 \%$ ginger juice. The results illustrated that treatment containing $L b$. paracasei subsp. tolerans WT631, Lb. brevis KP653 and Lb. del. subsp. lactis KP645 probiotic strains scored high levels of overall intensity (9.2, 9.2 and 9.3 respectively). 
Table 7 Sensory evaluation of probiotic ginger fermented milk

\begin{tabular}{|c|c|c|c|c|c|c|c|c|}
\hline Parameters & Control & KT615 & KP653 & KP645 & KP623 & WT631 & BM711 & BT734 \\
\hline \multicolumn{9}{|l|}{ Appearance } \\
\hline Syneresis & 7.5 & 6.5 & 6.2 & 6.4 & 6.5 & 6.3 & 6.1 & 5.5 \\
\hline \multicolumn{9}{|l|}{ homogeneity } \\
\hline Color & 8.7 & 7.2 & 7.2 & 7.4 & 7.2 & 7.5 & 7.3 & 7.1 \\
\hline Firmness & 8.9 & 8.3 & 8.1 & 8.3 & 8.3 & 8.6 & 8.4 & 7.2 \\
\hline \multicolumn{9}{|l|}{ Odor } \\
\hline Sour & 6.5 & 4.2 & 4.4 & 4.5 & 4.5 & 4.7 & 4.4 & 4.2 \\
\hline Sweet & 4.7 & 6.2 & 6.1 & 6.1 & 6.4 & 6.2 & 6.5 & 5.9 \\
\hline Oxidized & 0 & 0 & 0 & 0 & 0 & 0 & 0 & 0 \\
\hline \multicolumn{9}{|l|}{ Flavor/taste } \\
\hline Sour & 7.7 & 6.1 & 6.1 & 6.7 & 6.5 & 6.5 & 6.1 & 6.5 \\
\hline Sweet & 3.2 & 4.5 & 4.6 & 4.7 & 4.3 & 4.1 & 4.6 & 4.2 \\
\hline Salty & 0 & 0 & 0 & 0 & 0 & 0 & 0 & 0 \\
\hline Bitter & 0 & 1.2 & 1.2 & 1.2 & 1.2 & 1.2 & 1.2 & 1.2 \\
\hline Fermented milk & 8.8 & 7.1 & 8.1 & 8.2 & 8.5 & 8.5 & 5.2 & 5.1 \\
\hline Creamy & 8.9 & 8.1 & 9.2 & 9.1 & 8.3 & 9.2 & 6.1 & 6.1 \\
\hline \multicolumn{9}{|c|}{$\begin{array}{l}\text { Texture and mouth } \\
\text { feel }\end{array}$} \\
\hline Thickness & 7.8 & 8.2 & 8,7 & 8,7 & 8.3 & 8.9 & 6.4 & 6.5 \\
\hline Homogenous & 9.1 & 9.0 & 9.2 & 9.4 & 9.2 & 9.4 & 8.5 & 8.2 \\
\hline Mouth coating & 9.3 & 9.0 & 9.5 & 9.6 & 9.2 & 9.6 & 8.5 & 8.2 \\
\hline Smooth & 8.7 & 8.5 & 9.5 & 9.2 & 7.4 & 9.2 & 6.9 & 7.1 \\
\hline Slimy & 0 & 0 & 0 & 0 & 0 & 0 & 0 & 0 \\
\hline \multicolumn{9}{|l|}{ After taste } \\
\hline Overall intensity & $9.2 \pm 0.2$ & $8.2 \pm 0.8$ & $9.3 \pm 0.5$ & $9.2 \pm 1.7$ & $7.3 \pm 4.3$ & $9.2 \pm 0.3$ & $7.4 \pm 1.6$ & $6.5 \pm 1.3$ \\
\hline
\end{tabular}

- Averages \pm Standard deviation (SD) of three replicates.

- The evaluation of the intensity of the descriptors is done using a 10 unit scale.

- Overall sensory quality $=$ overall impression of the products.

\section{Conclusion}

Like the Father of Medicine Hippocrates, said "Let your food be your medicine and your medicine be your food" which clearly confirm a linkage between diet and health for human. We have to select healthy food have a functional and medicinal properties, antioxidant, antimicrobial, and have good sensory properties in the same time .

There is an ideal correlation between total phenol content and antioxidant activity that supports the idea of phenols as contributor of the antioxidant power of ginger juice when support the functional dairy product with it.

The results showed that the addition of ginger juice in milk at concentrations ranging from 1 to $15 \%(\mathrm{v} / \mathrm{v})$ reduced the coagulation time and $\mathrm{pH}$ of different yoghurt samples and increased the percentage of syneresis. Also, the supplementation of $2 \%$ ginger juice was observed to be optimum between all ginger juice concentrations added to milk for yogurt processing.

On another hand, the addition of selected probiotics strains to fermented milk with $2 \%$ ginger juice the obtained results showed that treatment containing $L b$. paracasei subsp. tolerans WT631, Lb. brevis KP653 and Lb. del. subsp. lactis KP645 probiotic strains scored high levels of overall intensity. 
In addition to that, there is little studies about the addition of fresh ginger juice to probiotic fermented milk and yoghurt to enhance its functional properties so, this study recommended to use fresh ginger juice as a fortified in fermented milk and studied the medical properties of products.

\section{Conflict of Interest}

The authors do not have any conflicts of interest.

\section{Acknowledgment}

The authors are grateful to Dr. Amira Darwish (City of Scientific Research and Technological Applications), for her help in determine antioxidant and total phenolic components in ginger juice.

\section{References}

Akhani S.P., Vishwakarma S.L. and Goyal R.K. 2004. Anti-diabetic activity of Zingiber officinale in streptozotocin-induced type I diabetic rats. Journal of Pharmacy and Pharmacology, 56: 101-105.

Akowuah G.A., Ismail Z., Norhayati I. and Sadikun A. 2005. The effects of different extraction solvents of varying polarities on polyphenols of Orthosiphon stamineus and evaluation of the free radical-scavenging activity. Food Chemistry, 93: 311-317.

Allam M.G., Darwish A.M., Ayad E.H., Shokery E.S. and Darwish S.M. 2017. Lactococcus species for conventional Karish cheese conservation. LWT-Food Science and Technology, 79: 625-631.

Alnaqdy A., Al-Jabri A., Al Mahrooqi Z., Nzeako B. and Nsanze H. 2005. Inhibition effect of honey on the adherence of Salmonella to intestinal epithelial cells in vitro. International Journal of Food Microbiology, 103: 347-351.

Al-Rimawi F., Abu-Lafi S., Abbadi J., Alamarneh A.A., Sawahreh R.A. and Odeh I. 2017. Analysis of phenolic and flavonoids of wild Ephedra alata plant extracts by LC/PDA and LC/MS and their antioxidant activity. African Journal of Traditional, Complementary, and Alternative Medicines, 14: 130-141.

Aly U.I., Abbas M.S., Taha H.S. and Gaber E.S.I. 2013. Characterization of 6-gingerol for in vivo and in vitro ginger (Zingiber officinale) using high performance liquid chromatography. Global Journal of Botanical Science, 1: 9-17.

AOAC International. 2016. Official methods of analysis 20th ed. G. W. Latimer (ed). AOAC International, Rockville, Maryland 20850-3250, USA.

Aruna G., Anjum A. and Noorjahan C.M. 2014. Combined effect of ginger and honey against salmonellosis. Global Journal for Research Analysis, 3:1-3.

Aswathy R.G., Ismail B., John R.P. and Nampoothiri K. M. 2008. Evaluation of the probiotic characteristics of newly isolated lactic acid bacteria. Applied Biochemistry and Biotechnology, 151: 244-255.

Atashak S., Peeri M., Azarbayjani M.A. and Stannard S.R. 2014. Effects of ginger (Zingiber officinale Roscoe) supplementation and resistance training on some blood oxidative stress markers in obese men. Journal of Exercise Science \& Fitness, 12: 26-30.

Ayyash M., Al-Nuaimi A.K., Al-Mahadin S. and Liu S. Q. 2018. In vitro investigation of anticancer and ACE-inhibiting activity, $\alpha$-amylase and $\alpha$-glucosidase inhibition, and antioxidant activity of camel milk fermented with camel milk probiotic: A comparative study with fermented bovine milk. Food chemistry, 239: 588-597. 
Badehnoosh B., Karamali M., Zarrati M., Jamilian M., Bahmani F., Tajabadi-Ebrahimi M. and Asemi Z. 2018. The effects of probiotic supplementation on biomarkers of inflammation, oxidative stress and pregnancy outcomes in gestational diabetes. The Journal of MaternalFetal \& Neonatal Medicine, 31: 1128-1136.

Bigliardi B. and Galati F. 2013. Innovation trends in the food industry: the case of functional foods. Trends in Food Science \& Technology, 31: 118-129.

Bubnov R.V., Babenko L.P., Lazarenko L.M., Mokrozub V.V. and Spivak M.Y. 2018. Specific properties of probiotic strains: relevance and benefits for the host. EPMA Journal, 9: 205223.

Charteris W.P., Kelly P.M., Morelli L. and Collins J.K. 1998. Development and application of an in vitro methodology to determine the transit tolerance of potentially probiotic Lactobacillus and Bifidobacterium species in the upper human gastrointestinal tract. Journal of Applied Microbiology, 84: 759-768.

Du Q., Ni S., Guo L., Song W., Zhao K., Liu N. and Tan Q. 2018. Effects of Zingiber officinalis (WILLD.) ROSC. Membranes on minor recurrent aphthous stomatitis: a randomized pragmatic trial. Journal of Traditional Chinese Medical Sciences, 5(1): 58-63.

El-Khalek A.B.A., El-Sayed H.S., Ibrahim G.A., El-Shafei K., El-Din H.M., Sharaf O.M. and El-Messery T.M. 2016. Phenolic compounds, microbial content and sensory evaluation of synbiotic labneh containing Ginger and probiotic. Int.J. Chem Tech Res, 9: 238-247

FAO/WHO 2002. Guidelines for the evaluation of probiotics in food. Joint FAO/WHO Working Group Report on Drafting Guidelines for the Evaluation of Probiotics in Food, London, Ontario, Canada.

Foster, S. 2011. Ginger (Zingiber officinale)-Your food is your medicine. Steven Foster Group pp: $1-5$.

Gounder D.K. and Lingamallu J. 2012. Comparison of chemical composition and antioxidant potential of volatile oil from fresh, dried and cured turmeric (Curcuma longa) rhizomes. Industrial Crops and Products, 38: 124-131.

Hasan H.A., Rasheed Raauf A.M., Abd Razik B.M. and Rasool Hassan B.A. 2012. Chemical composition and antimicrobial activity of the crude extracts isolated from Zingiber officinale by different solvents. Pharmaceut Anal Acta, 3(9): 1-5.

Ignat I., Volf I. and Popa V.I. 2011. A critical review of methods for characterization of polyphenolic compounds in fruits and vegetables. Food Chemistry, 126(4): 1821-1835.

Islam K., Rowsni A.A., Khan M.M., and Kabir M.S. 2014. Antimicrobial activity of ginger (Zingiber officinale) extracts against food-borne pathogenic bacteria. International Journal of Science, Environment and Technology, 3: 867-871.

Kang C.G., Hah D.S., Kim C.H., Kim Y.H., Kim E. and Kim J.S. 2011. Evaluation of antimicrobial activity of the methanol extracts from 8 traditional medicinal plants. Toxicological research, 27(1): 31-36.

Kerry R.G., Patra J.K., Gouda S., Park Y., Shin H.S. and Das G. 2018. Benefaction of probiotics for human health: A review. Journal of food and drug analysis, 26: 927-939.

Maizura M., Aminah A. and Wan Aida W.M. 2011. Total phenolic content and antioxidant activity of kesum (Polygonum minus), ginger (Zingiber officinale) and turmeric (Curcuma longa) extract. International Food Research Journal, 18: 529-534.

Majchrzak D., Lahm B. and Duerrschmid K. 2010. Conventional and probiotic yogurts differ in sensory properties but not in consumers' preferences. Journal of sensory studies, 25: 431446.

Markowiak P. and Śliżewska K. 2017. Effects of probiotics, prebiotics, and synbiotics on human health. Nutrients, 9: 1021. doi:10.3390/nu9091021

Mošovská S., Nováková D., and Kaliňák M. 2015. Antioxidant activity of ginger extract and identification of its active components. Acta Chimica Slovaca, 8(2): 115-119 
Mathew S. 2018. Comparative evaluation of antimicrobial efficacy of neem and ginger, to prove its effectiveness in decontaminating "Gutta Percha Cones"-An in vitro study. International Journal of Contemporary Research and Review, 9: 20258-20262.

Olejnik A., Lewandowska M., Obarska M. and Grajek W. 2005. Tolerance of Lactobacillus and Bifidobacterium strains to low $\mathrm{pH}$, bile salts and digestive enzymes. Electronic Journal of Polish Agricultural Universities, Food Science and Technology, 8(1): 5.

Ong L., Henriksson A. and Shah N.P. (2006). Development of probiotic Cheddar cheese containing Lactobacillus acidophilus, Lb. casei, Lb. paracasei and Bifidobacterium spp. and the influence of these bacteria on proteolytic patterns and production of organic acid. International Dairy Journal, 16(5): 446-456

Panpatil V.V., Tattari S., Kota N., Nimgulkar, C. and Polasa K. 2013. In vitro evaluation on antioxidant and antimicrobial activity of spice extracts of ginger, turmeric and garlic. $\mathrm{J}$. Pharmacogn. Phytochem., 2: 143-148.

Pawar N., Pai S., Nimbalkar M. and Dixit G. 2011. RP-HPLC analysis of phenolic antioxidant compound 6-gingerol from different ginger cultivars. Food Chemistry, 126: 1330-1336.

Pessoa W.F.B., Melgaço A.C.C., de Almeida M.E., Ramos L.P., Rezende R.P. and Romano C. C. 2017. In Vitro Activity of Lactobacilli with Probiotic Potential Isolated from Cocoa Fermentation against Gardnerella vaginalis. BioMed research international, https://doi.org/10.1155/2017/3264194

Plaza-Díaz J., Ruiz-Ojeda F.J., Vilchez-Padial L.M. and Gil A. 2017. Evidence of the antiinflammatory effects of probiotics and synbiotics in intestinal chronic diseases. Nutrients, 9(6): 555. doi: 10.3390/nu9060555.

Policegoudra R.S., Abiraj K., Gowda D.C. and Aradhya S.M. 2007. Isolation and characterization of antioxidant and antibacterial compound from mango ginger (Curcuma amada Roxb.) rhizome. Journal of Chromatography B, 852: 40-48.

Sakanaka S., Tachibana Y. and Okada Y. 2005. Preparation and antioxidant properties of extracts of Japanese persimmon leaf tea (kakinoha-cha). Food chemistry, 89: 569-575.

Shehata M.G., El Sohaimy S.A., El-Sahn M.A. and Youssef M.M. 2016. Screening of isolated potential probiotic lactic acid bacteria for cholesterol lowering property and bile salt hydrolase activity. Annals of Agricultural Sciences, 61: 65-75.

Singh P., Srivastava S., Singh V.B., Sharma P. and Singh D. 2018. Ginger (Zingiber officinale): A Nobel Herbal Remedy. Int.J.Curr.Microbiol.App.Sci Special Issue-7: 4065-4077.

Skibsted, L. H. 2010. Oxidation in foods and beverages and antioxidant applications: Vol. 1: Understanding mechanisms of oxidation and antioxidant activity. ed. / Eric A. Decker; Ryan J. Elias; D. Julian McClements. Woodhead Publishing Limited, 2010. p. 3-35.

Srisuvor N., Chinprahast N., Prakitchaiwattana C. and Subhimaros S. 2013. Effects of inulin and polydextrose on physicochemical and sensory properties of low-fat set yoghurt with probiotic-cultured banana purée. LWT-Food science and Technology, 51: 30-36.

Stoilova I., Krastanov A., Stoyanova A., Denev P. and Gargova S. 2007. Antioxidant activity of a ginger extract (Zingiber officinale). Food Chemistry, 102: 764-770.

Su H.P., Huang M.J. and Wang H.T. 2009. Characterization of ginger proteases and their potential as a rennin replacement. Journal of the Science of Food and Agriculture, 89: 11781185.

Tamime A.Y. and Marshall V.M.E. 1997. Microbiology and technology of fermented milks. In: Microbiology and biochemistry of cheese and fermented milk. $2^{\text {nd }}$ ed., Law, B.A. (Ed.). London: Blackie Academic and Professionals, pp: 57-152.

Tohma H., Gülçin İ., Bursal E., Gören A.C., Alwasel S.H. and Köksal E. 2017. Antioxidant activity and phenolic compounds of ginger (Zingiber officinale Rosc.) determined by HPLC-MS/MS. Journal of Food Measurement and Characterization, 11: 556-566. 
Valko M., Rhodes C., Moncol J., Izakovic M.M. and Mazur M. 2006. Free radicals, metals and antioxidants in oxidative stress-induced cancer. Chemico-Biological Interactions, 160: 1-40.

Vijayaram S. and Kannan S. 2018. Probiotics: The marvelous factor and health benefits. Biomedical and Biotechnology Research Journal (BBRJ), 2: 1-8.

Wang H.M., Chen C.Y., Chen H.A., Huan W.C., Lin W.R., Chen T.C. and Chen Y.H. (2010). Zingiber officinale (ginger) compounds have tetracycline resistance modifying effects against clinical extensively drug-resistant Acinetobacter baumannii. Phytotherapy research, 24: $1825-1830$.

Zadeh J.B. and Kor N.M. 2014. Physiological and pharmaceutical effects of Ginger (Zingiber officinale Roscoe) as a valuable medicinal plant. European Journal of Experimental Biology, 4(1): 87-90.

Zinedine A. and Faid, M. 2007. Isolation and characterization of strains of Bifidobacteria with probiotic proprieties in vitro. World Journal of Dairy \& Food Sciences, 2(1): 28-34. 